\title{
Abnormalities of hypothalamic-pituitary-adrenal and hypothalamic-somatotrophic axes in Fawn-Hooded rats
}

\author{
Francisca Gómez ${ }^{1}$, Pilar Graugés ${ }^{1}$, Asunción López-Calderón ${ }^{2}$ and Antonio Armario ${ }^{1}$ \\ ${ }^{1}$ Unitat de Fisiologia Animal, Departament de Biologia Cellular, de Fisiologia i d'Immunologie, Facultat de Cièncias, \\ Universitat Autònoma de Barcelona, 08193 Bellaterra, Barcelona, Spain and ${ }^{2}$ Departamento de Fisiología, Facultad de Medicina, \\ Universidad Complutense de Madrid, Madrid, Spain \\ (Correspondence should be addressed to A Armario; Email: Armario@cc.uab.es)
}

\begin{abstract}
Fawn-Hooded (FH) rats show central and peripheral abnormalities in serotoninergic functions and have attracted attention as an animal model of some pathologies, including depression and hypertension. In addition, these rats show a reduced growth rate. As the hypothalamic-pituitary-adrenal (HPA) axis has been implicated in both depression and hypertension, and the hypothalamicsomatotrophic (HSM) axis has a major role in growth, these two endocrine axes were characterised in FH rats as compared with outbred Sprague-Dawley (SD) rats in basal conditions. FH rats showed normal serum ACTH and corticosterone concentrations, but reduced serum corticosterone binding capacity. At a central level, normal expression of mRNA for glucocorticoid type II receptors in the hippocampal formation and mRNA for corticotrophin-releasing factor (CRF) in the paraventricular nucleus of the hypothalamus were observed in FH rats, whereas expression of mRNA for CRF in the central nucleus of the amygdala was enhanced compared with the expression in SD rats. Serum GH concentrations were normal in FH rats, IGF-I tended to be lower, and mRNA for somatostatin (SRIF) in the periventricular nucleus of the hypothalamus was significantly lower in FH rats than in SD rats. The reduced SRIF gene expression in rats with normal or slightly reduced GH and IGF-I, respectively, might be secondary to a defective central and peripheral response to IGF-I, compatible with the reduced growth of FH rats. The present results suggest that FH rats have abnormalities in both HPA and HSM axes that might be related to some of their physiopathological characteristics.
\end{abstract}

European Journal of Endocrinology 141 290-296

\section{Introduction}

Fawn-Hooded (FH) rats were first characterised by a defect in platelet aggregation and serotonin content $(1,2)$. The altered serotoninergic function became a main focus of research, because of the possible role of serotonin in depression (3). Contradictory results have been reported regarding platelet and synaptosomal uptake of serotonin and ${ }^{3} \mathrm{H}$-imipramine binding to membranes in FH rats (4-6), but some behavioural and endocrine responses to serotoninergic agents have been found to be reduced in $\mathrm{FH}$ rats as compared with both Sprague-Dawley (SD) and Wistar rats (7-9), suggesting hypofunctionality of the serotoninergic system.

Apart from some endocrine responses to serotoninergic agents, the endocrine system of FH rats has not been characterised, and only a few investigations have been undertaken to study the hypothalamic-pituitaryadrenal (HPA) axis. Initially, high basal corticosterone concentrations that were normalised by administration of antidepressant agents were reported in $\mathrm{FH}$ rats (10), in support of the validity of FH rats as an animal model of depression. However, there are several findings arguing against this hypothesis. First, true basal activity of the HPA axis does not appear to be supranormal in $\mathrm{FH}$ rats, as the same laboratory that reported basal hypercorticosteronaemia subsequently showed normal corticosterone concentrations (11) - a finding corroborated by our own results (12). Secondly, FH rats showed lower relative adrenal weight and greater relative thymus weight as compared with both Wistar and SD rats $(11,12)$. Thirdly, activity of $\mathrm{FH}$ rats in the forced swimming test, which is presumed to evaluate depression-like behaviour $(13,14)$, is dependent on the particular substrain used (15).

Although the validity of $\mathrm{FH}$ rats as an animal model of depression is questionable, $\mathrm{FH}$ rats show other important abnormalities, such as spontaneous hypertension and reduced growth $(2,8)$. Therefore, a more detailed endocrinological characterisation of this strain might be potentially important in establishing its suitability for use as a model for physiopathology. Thus the present work aimed to extend the endocrinological characterisation of $\mathrm{FH}$ rats, focusing on the HPA and 
hypothalamic-somatotrophic (HSM) axes. The rationale for such a focus was as follows: (i) in the rat, the HPA and HSM are under stimulatory serotoninergic control $(16,17)$; (ii) various components of the HPA axis appear to be involved in cardiovascular function and the development of hypertension $(18,19)$; (iii) abnormalities of the HSM axis are expected in $\mathrm{FH}$ rats, as they eat and grow less than Wistar or SD rats, and the HSM axis is closely related to both food intake and growth control (20-23); and (iv) the HPA and HSM axes are interconnected at both hypothalamic and peripheral levels $(24-27)$.

\section{Material and methods}

\section{Animals}

Male FH and SD rats, approximately 70 days old when killed, were used. At that time their average body weights were 238 and $454 \mathrm{~g}$ respectively. FH rats were obtained from NCI-Frederick Cancer Research and Development Centre (Frederick, Maryland, USA) and SD rats were raised in the breeding centre of the Universitat Autònoma de Barcelona. The rats were housed two per cage in a controlled environment (lights on from 07.30 to $19.30 \mathrm{~h}$, temperature $22^{\circ} \mathrm{C}$ ) for 25 days before being killed. Food and water were always available ad libitum.

\section{Experimental procedures}

The experimental procedures used in this work had previously been approved by the ethics committee for animal experimentation of the Universitat Autònoma de Barcelona.

The animals were killed quickly by decapitation without stress, in an adjacent room within $10 \mathrm{~s}$ after they had been removed from the animal room, between 1000 and $1100 \mathrm{~h}$. The trunk blood was collected, maintained and centrifuged at $4{ }^{\circ} \mathrm{C}$. Brains were quickly removed and frozen on isopentanol (cooled in a bath of dry ice with $70 \%$ ethanol) for in situ hybridisation experiments. Serum was frozen at $-20^{\circ} \mathrm{C}$ and brain at $-80^{\circ} \mathrm{C}$, until required for assay.

\section{Hormone analysis}

Total serum corticosterone was measured by radioimmunoassay (RIA) using a procedure based on one described previously (28), with small modifications (12). Serum ACTH was assayed immunoradiometrically, using a commercial kit (Nichols, San Juan Capistrano, CA, USA). Plasma concentrations of growth hormone $(\mathrm{GH})$ and insulin-like growth factor I (IGF-I) were measured by a double-antibody RIA, using reagents provided by the NIDDK, Rat Pituitary Hormone Program (University of Maryland, School of Medicine, Baltimore, MD, USA). Levels of GH were expressed in terms of NIDDK rat-RP-2 standard. The level of detection of $\mathrm{GH}$ was $10 \mathrm{pg}$, and the intra-assay coefficient of variation was 3\%. Serum or plasma IGF-I binding proteins were removed by an acid-ethanol procedure (29). The standard used was IGF-I A52-EPD186 (kindly provided by Eli Lilly \& Company). Concentrations of IGF-I were expressed as nmol/l with respect to the molecular weight of human IGF-I, as the research sample of IGF-I was prepared by recombinant DNA technology using unique methods $(30,31)$, this $70-$ residue peptide having a molecular weight of 7649 Da. The intra-assay coefficient of variation was $8 \%$; samples from one experiment were run in the same assay.

\section{Corticosteroid binding globulin}

Apparent affinity $\left(K_{\mathrm{d}}\right)$ and number of binding sites $\left(B_{\max }\right)$ for corticosteroid binding globulin (CBG) were determined by a binding assay in stripped serum, using $\left[{ }^{3} \mathrm{H}\right]$ corticosterone (Amersham, Bucks, UK) with a specific activity of $82 \mathrm{Ci} / \mathrm{mmol}$. One hundred microlitres diluted $(1: 100)$ serum were incubated with $\left[{ }^{3} \mathrm{H}\right]$ corticosterone concentrations varying from 0.1 to $40 \mathrm{nmol} / \mathrm{l}$ in a final volume assay of $500 \mu \mathrm{l}$. Non-specific binding was measured using 500-fold excess of unlabelled corticosterone. The assay buffer was $0.01 \mathrm{~mol} / \mathrm{l}$ phosphate $(\mathrm{pH} 8.2)$ containing $0.9 \% \mathrm{NaCl}$ and $1 \%$ gelatine. The incubation lasted for $30 \mathrm{~min}$ at $37^{\circ} \mathrm{C}$ and $15 \mathrm{~min}$ at $4{ }^{\circ} \mathrm{C}$. Five hundred microlitres of a solution containing dextran T70 $(0.1 \%)$ and charcoal $(1 \%)$ were added at $4{ }^{\circ} \mathrm{C}$ and, $10 \mathrm{~min}$ later, the tubes were centrifuged at the same temperature for $15 \mathrm{~min}$. In a pilot experiment, a $28 \%$ dissociation with regard to time 0 had been found, and the values were corrected accordingly. Binding parameters were estimated by non-linear regression fit using Inplot 4.0 (GraphPad-Software Inc.; San Diego, CA, USA).

\section{In situ hybridisation assay}

Serial coronal sections $(20 \mu \mathrm{m})$ through the periventricular (PeN; bregma -0.92, -1.40) and paraventricular (PVN; bregma -1.80, -2.30) nuclei of the hypothalamus, the central nucleus of the amygdala (CeA; bregma $-2.30,-2.80)$ and the hippocampal formation (bregma $-3.30,-3.80$ ) were cut in a cryostat at $-20^{\circ} \mathrm{C}$, in accordance with flat brain stereotaxic coordinates (32). Sections were mounted onto poly-L-lysine-coated slides (Sigma) and stored in boxes at $-80{ }^{\circ} \mathrm{C}$ until required for hybridisation. For somatostatin (SRIF), we used a 45-base cDNA oligomer with the following sequence: 5'3'CCAGAAGAAGTTCTTGCAGCCAGCTTTGCGTTCCCGGGGTGT (Genosys), kindly provided by Dr S Arancibia. For corticotrophinreleasing factor (CRF), a 48-base cDNA oligomer complementary to the mRNA sequence encoding 64-111 (NEN Products, du Pont, Boston, MA, USA) was used. They were tailed on the $3^{\prime}-\mathrm{OH}$ end with 
$\left[\alpha-{ }^{35}\right.$ S]deoxyadenosine triphosphate (specific activity $>1000 \mathrm{Ci} / \mathrm{mmol}$, Amersham) using terminal deoxynucleotyl transferase (Boehringer Mannheim, Mannheim, Germany). Probe specificity was approximately $10^{6}$ d.p.m./pmol. For glucocorticoid receptor (GR) mRNA, cRNA antisense probe was used. The antisense GR probe was transcribed from a 500-bp rat cDNA fragment that encodes for the N-terminal region of the rat liver GR (33) (courtesy of K R Yamamoto and R Miesfeld, Dept Biochemistry, University of Arizona, Tucson, AZ, USA). This fragment was subcloned from a 2.8-kb fragment and transfected into pGEM3 plasmid (courtesy of M C Bohn, Dept Pediatrics, Northwestern University Medical School, Chicago, IL, USA). The probe was labelled with uridine $\left[5^{\prime} \alpha{ }^{35} S\right]$ triphosphate (Amersham). The probe was used when incorporation of the radioactive nuclide into the probe was $>70 \%$. (For hybridisation procedures, see reference (34).) Sections were exposed to Kodak X-OMAT AR film for 3 (SRIF mRNA, PeN), 14 (CRF mRNA, PVN and GR mRNA, hippocampus) and 21 days (CRF mRNA, CeA). Four to six animals per strain were processed (the remaining rats were used for other experimental purposes). Staining of every third section with thionine was helpful in the anatomical identification of the regions.

\section{Quantification of autoradiograms}

From each animal, four hypothalamic and eight CeA sections were considered. Optical density (OD) of autoradiograms was quantified on the basis of a standard curve calculated from a set of carbon-14 microscales, which is comparable to sulphur-35 microscales (Amersham), after shading and background correction using a computer-assisted image analyser (LeicaQ500 MC, Leica, Barcelona, Spain). The various regions to be analysed were selected into a fixed rectangular area, the grey level of which had previously been standardised using several sections, to demarcate the nucleus of interest. After that, the same rectangular area and grey level were used for all sections and animals. The number of pixels and their mean OD were multiplied to obtain arbitrary units. The background from each section was measured in an adjacent area, maintaining the same conditions of rectangular area and grey levels, and the values obtained were subtracted from the appropriate specific signal. Sections treated by RNAse A digestion were used as negative control for SRIF and CRF, whereas sections hybridised with $\left.{ }^{35} \mathrm{~S}\right]$ sense probe were used for GR. The average value of all sections from each animal was considered as the unit for the statistical analysis.

All biochemical and in situ hybridisation samples were processed in the same assay, and in the same cassette in the case of in situ hybridisation analyses. Intra-assay coefficients of variation of the biochemical analyses were always less than $8 \%$.
Table 1 Body weight and food intake in Sprague-Dawley and Fawn-Hooded rats. Results are expressed as means \pm S.E.M. ( $n=8 \mathrm{rats} /$ strain, except for food intake, where $n=4$ cages).

\begin{tabular}{lcc}
\hline & Sprague-Dawley & Fawn-Hooded \\
\hline Initial body weight $(\mathrm{g})$ & $447.5 \pm 14.6$ & $235.1 \pm 10.3^{* * *}$ \\
Final body weight $(\mathrm{g})$ & $464.6 \pm 15.1$ & $241.8 \pm 10.1^{* * *}$ \\
Body weight increment $(\mathrm{g})$ & $17.4 \pm 3.1$ & $6.6 \pm 0.8^{* *}$ \\
Food intake $(\mathrm{g} /$ rat per day) & $28.0 \pm 0.6$ & $17.5 \pm 0.3^{* * *}$ \\
\hline
\end{tabular}

${ }^{* *} P<0.01 ;{ }^{* * *} P<0.001$ (t-tests).

\section{Statistics}

Statistical analysis was by Student's $t$-test. Where necessary $\left(B_{\max }\right.$ for $\left.\mathrm{CBG}\right)$, data were log-transformed to achieve homogeneity of variances.

\section{Results}

As Table 1 shows, FH rats showed reduced food intake and lower initial and final body weights compared with SD rats $(P<0.001)$. Body weight gain was also significantly lower $(P<0.01)$ in $\mathrm{FH}$ rats.
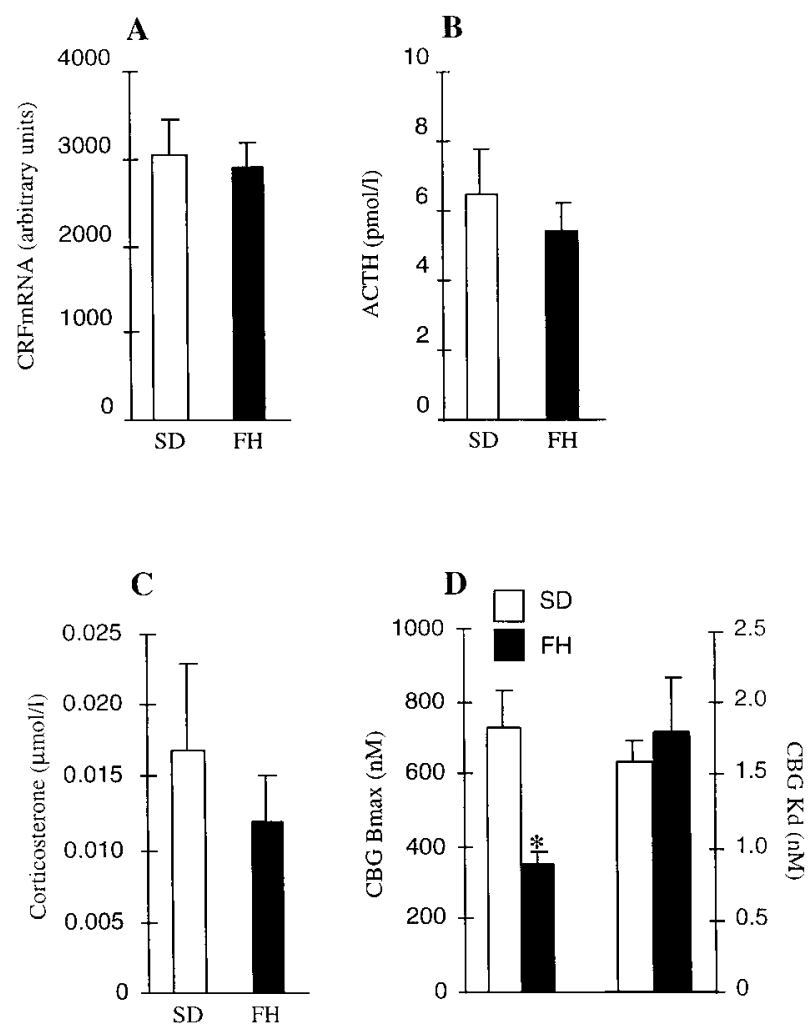

Figure 1 Comparison of HPA axis in SD rats (open bars) and $\mathrm{FH}$ rats (closed bars). (A) CRF mRNA levels in the PVN; (B) serum $\mathrm{ACTH}$ concentrations; (C) serum corticosterone concentrations; (D) $B_{\max }$ and $K_{\mathrm{d}}$ for CBG. Results are expressed as means \pm S.E.M. $(n=4$ animals per strain for CRF mRNA; $n=7-8$ for ACTH, corticosterone and CBG values). ${ }^{*} P<0.005$ ( $t$-test) compared with SD rats. 


\section{Sprague-Dawley}

A

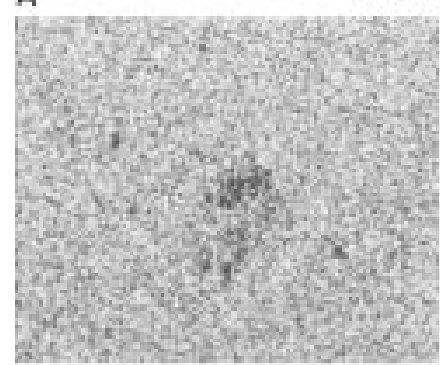

CeA CRF mRNA

B
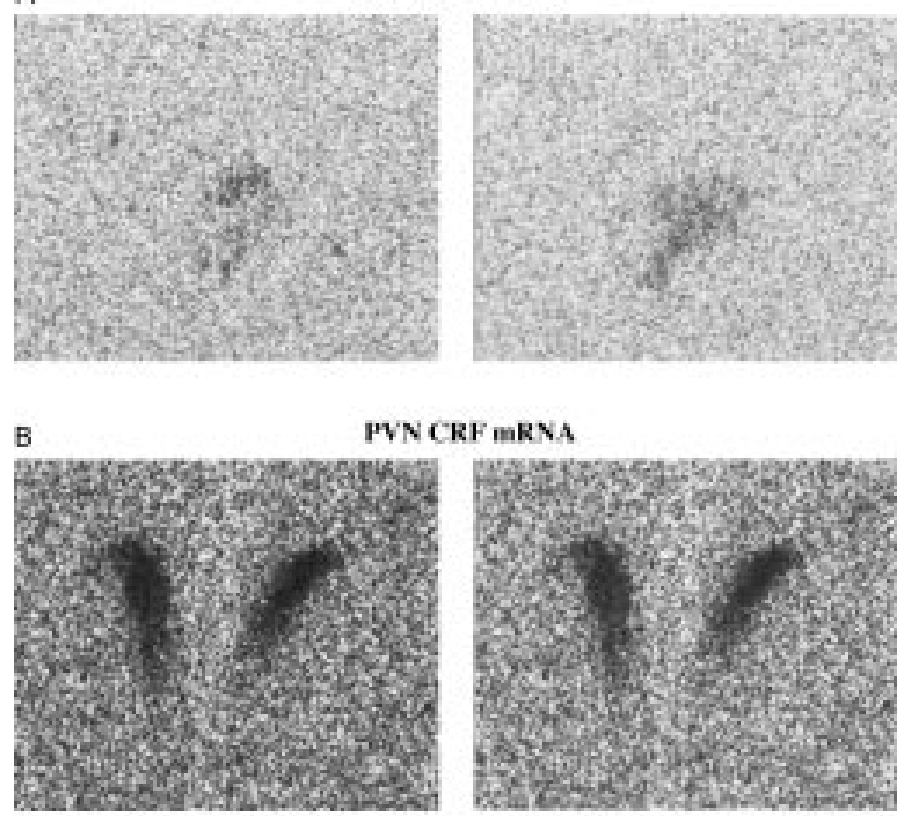

Fawn-Hooded

C

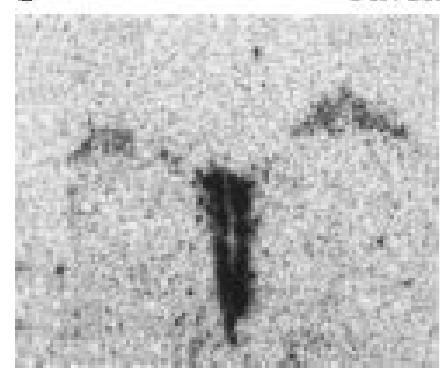

PEV SRIF mRNA

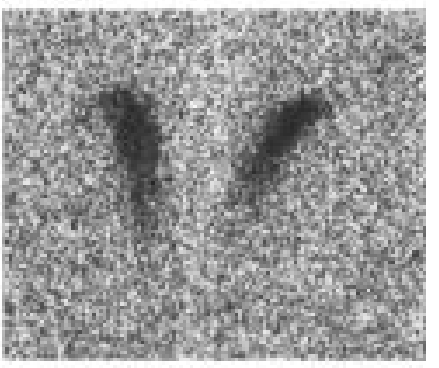

Figure 2 Bright-field images of $(A)$ the $\mathrm{CeA}$; $(\mathrm{B})$ the PVN and $(C)$ the $\mathrm{PeN}$ from SD rats (left column) and $\mathrm{FH}$ rats (right column) rats after in situ hybridisation with oligonucleotide probes to CRF mRNA (A, B) and SRIF mRNA (C). There is an increase in CRF mRNA labelling in the $\mathrm{CeA}$ in $\mathrm{FH}$ rats compared with SD rats, whereas a lower signal in SRIF mRNA is observed in the PeN of FH rats. No differences between strains can be seen in the CRF mRNA labelling in the PVN.

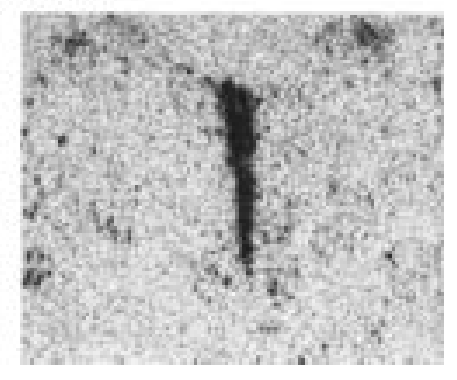

Resting serum ACTH and corticosterone concentrations were similar in the two strains (Fig. 1B and $\mathrm{C}$, respectively). However, binding properties of CBG differed: $\mathrm{FH}$ rats showed a similar $K_{\mathrm{d}}$ and a lower $B_{\max }(P<0.005)$ than SD rats (Fig. 1D). Whereas in the PVN the CRF gene expression was similar in the two strains (Figs 1A, 2B), in the CeA it was greater $(P<0.01)$ in $\mathrm{FH}$ than in SD rats (Figs $2 \mathrm{~A}, 3)$. No differences were found between strains in GR mRNA levels in the areas of the hippocampus that were studied - the dentate gyrus and CA1 (Fig. 4).

Plasma GH concentrations did not differ among the two strains (Fig. 5B), IGF-I tended to be lower in FH rats $(P=0.075$; Fig. $5 \mathrm{C})$, and mRNA for SRIF in the $\mathrm{PeN}$ was significantly lower in $\mathrm{FH}$ than in SD rats $(P<0.02$; Figs 2C, 5A).

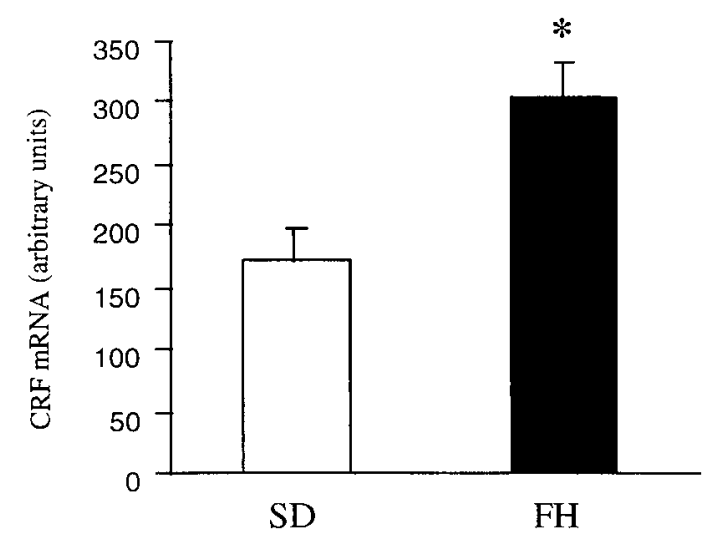

Figure $3 \mathrm{CRF}$ mRNA levels in the CeA in SD rats (open bars) and $\mathrm{FH}$ rats (closed bars). Results are expressed as means \pm S.E.M. $\left(n=4\right.$ animals per strain). ${ }^{*} P<0.01$ ( $t$-test) compared with SD rats. 


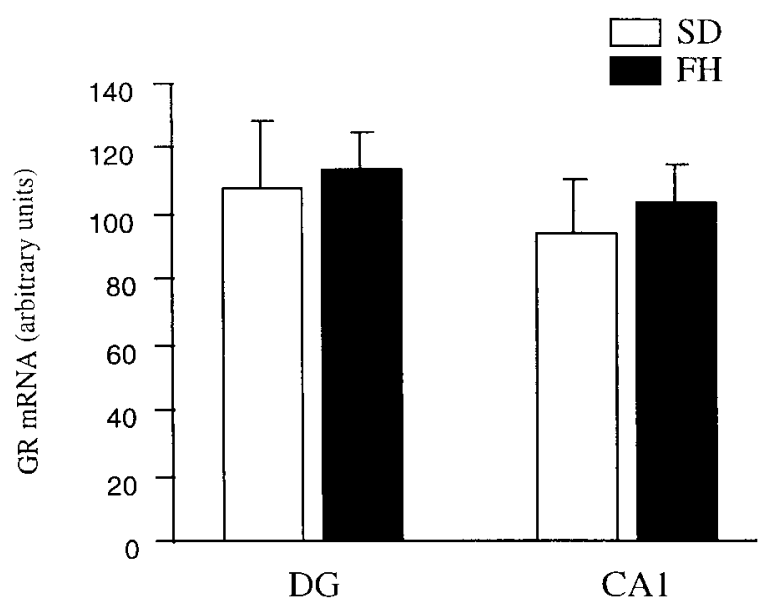

Figure $4 \mathrm{GR}$ mRNA levels in dentate gyrus (DG) and the CA1 area of the hippocampal formation in SD rats (open bars) and $\mathrm{FH}$ rats (closed bars). Results are expressed as means \pm S.E.M. ( $n=4$ animals per strain).

\section{Discussion}

The present data demonstrate that $\mathrm{FH}$ rats differed from SD rats in the HPA and HSM axes in basal conditions. HPA activity was similar in the two strains, with the exception of a reduction in plasma CBG activity in FH rats. mRNA for CRF in the CeA was found to be increased in FH rats, suggesting possible hypersensitivity of FH rats to aversive stimuli. Regarding the HSM axis, normal peripheral concentrations of GH and IGF-I, accompanied by reduced SRIF gene expression in the PeN nucleus, were observed in FH rats.

Resting concentrations of ACTH and corticosterone were found to be similar in FH and SD rats. Although high basal corticosterone concentrations had previously been found in FH rats compared with Wistar rats (10), more recent papers, including one from the same laboratory that originally reported hypercorticosteronaemia, have reported normal basal concentrations of ACTH and corticosterone in FH rats, as compared with either Wistar or SD rats $(11,12)$. Therefore, earlier results showing higher than usual concentrations of serum/plasma corticosterone in $\mathrm{FH}$ rats could have been due to stress associated with blood sampling. We found a reduced corticosterone binding capacity of serum in FH rats that appears to be due to a lower $B_{\max }$, rather than to changes in affinity $\left(K_{\mathrm{d}}\right)$. From the classical point of view of steroid action, a reduction in CBG would increase free corticosterone, which in turn would enhance its biological activity. However, this view has been challenged by the existence of intracellular CBG in several tissues and the possibility has been suggested that CBG might contribute to corticosterone uptake by cells and its interaction with intracellular receptors (35). In fact, there are no signs of glucocorticoids hyperactivity in FH rats. Rather, their greater thymus weight (12) and their tendency to
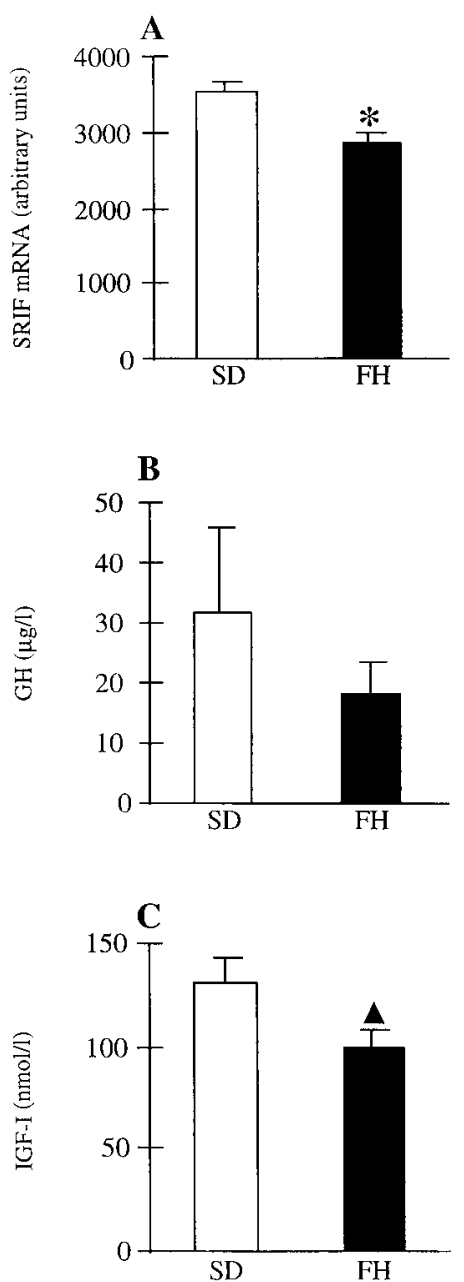

Figure 5 Comparison of HSM axis in SD rats (open bars) and $\mathrm{FH}$ rats (closed bars). (A) SRIF mRNA levels in the PeN; (B) serum GH concentrations; (C) serum IGF-I concentrations. Results are expressed as means \pm S.E.M. $(n=7-8$ animals per strain). ${ }^{*} P<0.02$ and ${ }^{\star} P=0.075$ (t-test) compared with SD rats.

develop inflammatory diseases (11) might be indicative of HPA hypoactivity. At higher levels of the HPA axis (mRNA for GR in the hippocampus, mRNA for CRF in the PVN, and serum ACTH concentrations), no differences were observed between the strains. Therefore, there is no evidence for either enhanced adrenocorticotrophic function or altered glucocorticoid negative feedback, the two major endocrine alterations in depression (36), in FH rats. Comparing FH and Wistar rats, no evidence for enhanced pituitaryadrenal function was observed (11). In addition, the activity of our particular substrain of $\mathrm{FH}$ rats in the forced swimming test, a putative animal model for the evaluation of depression-like behaviour in rodents $(13,14)$, was found to be greater than that of SD rats in a previous report (12). All these data argue against consideration of these rats as a putative animal model of depression. 
Although mRNA for CRF in hypothalamic PVN was found to be normal in FH rats, mRNA for CRF in the $\mathrm{CeA}$ was found to be increased in $\mathrm{FH}$ rats compared with SD rats. This is in accordance with a previous report comparing $\mathrm{FH}$ rats (obtained from the same breeder as the present FH rats) and Wistar rats (11), and suggests that enhanced expression of mRNA for CRF in the $\mathrm{CeA}$ is a consistent finding. Whether or not this factor might contribute to the development of hypertension in FH rats remains to be the subject of direct study. Nevertheless, several findings favour a possible role of CRF in the CeA: (i) this area is crucial for the integration of the response to aversive stimuli (37); (ii) $\mathrm{CRF}$ in the CeA appears to elicit cardiovascular and stress-like behavioural effects $(38,39)$; (iii) stress has been considered to be an aetiological factor in hypertension (19); (iv) stress increases CRF release and mRNA for CRF in the CeA $(40,41)$.

FH rats showed normal serum GH concentrations and a marginally significant reduction in serum IGF-I compared with SD rats. IGF-I is known to be under the control of $\mathrm{GH}$ and to mediate most of the physiological actions of $\mathrm{GH}$, including growth promotion (42). As FH rats achieve a lower body weight than SD rats, altered GH and IGF-I concentrations should have been expected. Although a clear trend toward lower IGF-I concentrations was observed in FH rats, this finding might not be sufficient to explain the low growth rate of $\mathrm{FH}$ rats and it is possible that an altered expression of IGF-I receptors or a change in the capacity of blood to bind IGF-I might alter the responsiveness of the tissues of FH rats to IGF-I. The reduction in SRIF mRNA in the $\mathrm{PeN}$ of FH rats might not have consequences on peripheral somatotrophic activity, as no evidence for altered GH secretion was observed in the present experiment. Although release of SRIF into the median eminence was not measured in FH rats, it is unlikely, on the basis of our present results, that the reported reduced $\mathrm{GH}$ response to serotoninergic agonists in $\mathrm{FH}$ rats $(7,9)$ could be explained by an enhanced somatostatinergic tone. Reduced mRNA for SRIF in the presence of normal GH and IGF-I concentrations could be the consequence of a defective response of $\mathrm{PeN}$ somatostatinergic neurones to GH and IGF-I, or to a reduction in the biological activity of IGF-I, as both hormones exert a positive feedback on $\mathrm{PeN}$ somatostatinergic activity (43-48). The hypothesis of a defective cellular response to GH or IGF-I is compatible with the dramatic reduction of growth that is observed in $\mathrm{FH}$ rats.

Although serotoninergic function appears to be defective of FH rats (see Introduction) and serotonin is positively involved in the control of both the HPA and HSM axes in the rat $(16,17)$, the present data suggest that such a defective serotonin function in $\mathrm{FH}$ rats exerts no significant contribution to the maintenance of normal activity of the HPA and HSM axes. In contrast, a contribution of defective serotoninergic function to the enhanced gene expression of CRF in the CeA should not be disregarded taking into account that serotoninergic innervation of amygdaloid nuclei is involved in fear-related behaviour (49).

In summary, the present results indicate that $\mathrm{FH}$ rats have some abnormalities of HPA and HS axes, compared with SD rats. However, these abnormalities, and the behaviour of $\mathrm{FH}$ rats in the forced swimming test, are not those expected in an animal model of depression. Nevertheless, although these endocrine alterations are not relevant to the consideration of FH rats as a model of depression, they might play a part in some other behavioural and physiological alterations observed in this strain.

\section{Acknowledgements}

This work was partially supported by grants DGICYT PB92-0854 and CIRIT SGR95-00499. Thanks are given to the National Cancer Institute for providing us with the Fawn-Hooded rats; to Eli Lilly \& Company for the IGF-I A52-EPD-186 standard; to Dr Sandor Arancibia for the cDNA oligomer complementary for the SRIF mRNA and to Dr Martha C Bohn for the pGEM3 plasmid.

\section{References}

1 Tschopp TB \& Zucker MB. Hereditary defect in platelet function in rats. Blood 197240 217-226.

2 Provoost AP \& De Keijzer MH. The Fawn-Hooded rat: a model for chronic renal failure. In Experimental and Genetic Rat Models of Chronic Renal Failure, pp 100-114. Eds N Gretz \& M Strauch. Basel: Karger, 1993.

3 Pryor JC \& Sulser F. Evolution of the monoamine hypotheses of depression. In Biological Aspects of Affective Disorders, pp 77-94. Eds RW Horton \& CLE Katona. London: Academic Press, 1991.

4 Arora RC, Tong C, Jackman HL, Stoff D \& Meltzer HY. Serotonin uptake and imipramine binding in blood platelets and brain of Fawn-Hooded and Sprague-Dawley rats. Life Sciences 198333 437-442.

5 Dumbrille-Ross A \& Tang SW. Absence of high-affinity $\left[{ }^{3} \mathrm{H}\right]$ imipramine binding in platelets and cerebral cortex of Fawn-Hooded rats. European Journal of Pharmacology 198172 137-138.

6 Ieni JR, Tobach E, Zukin SR, Barr GA \& Van Praag HM. Multiple $\left[{ }^{3} \mathrm{H}\right]$ imipramine binding sites in brains of male and female FawnHooded and Long-Evans rats. European Journal of Pharmacology $1985112261-264$.

7 Aulakh CS, Wozniak KM, Hill JL, Devane CL, Tolliver TJ \& Murphy DL. Differential neuroendocrine responses to the 5-HT agonist $m$-chlorophenylpiperazine in Fawn-Hooded rats relative to Wistar and Sprague-Dawley rats. Neuroendocrinology 198848 401-406.

8 Wang P, Aulakh CS, Hill JL \& Murphy DL. Fawn hooded rats are subsensitive to the food intake suppressant effects of 5-HT agonists. Psychopharmacology 198894 558-562.

9 Aulakh CS, Hill JL, Lesch KP \& Murphy DL. Functional subsensitivity of 5-hydroxytryptamine ${ }_{1 \mathrm{c}}$ or alpha $_{2}$ adrenergic heteroreceptors mediating clonidine-induced growth hormone release in the Fawn-Hooded rat strain relative to the Wistar rat strain. Journal of Pharmacology and Experimental Therapeutics 1992262 1038-1043.

10 Aulakh CS, Hill JL \& Murphy DL. Attenuation of hypercortisolemia in Fawn-Hooded rats by antidepressant drugs. European Journal of Pharmacology 1993240 85-88. 
11 Altemus M, Smith MA, Diep V, Aulakh CS \& Murphy DL. Increased mRNA for corticotropin releasing hormone in the amygdala of Fawn-Hooded rats: a potential animal model of anxiety. Anxiety 1994/1995 $1251-257$.

12 Lahmame A, Gómez F \& Armario A. Fawn-Hooded rats show enhanced active behaviour in the forced swimming test, with no evidence for pituitary-adrenal axis hyperactivity. Psychopharmacology $199612574-78$.

13 Solt RD. Behavioral despair. In Antidepressants: Neurochemical, Behavioral, and Clinical Perspectives, pp 121-138. Eds SJ Enna et al. New York: Raven Press, 1981.

14 Borsini F \& Meli A. Is the forced swimming test a suitable model for revealing antidepressant activity? Psychopharmacology 1988 94 147-160.

15 Overstreet DH \& Rezvani AH. Behavioral differences between two inbred strains of Fawn-Hooded rat: a model of serotonin dysfunction. Psychopharmacology $1996128328-330$.

16 Müller EE. Neural control of somatrotopic function. Physiological Reviews 198767 962-1053.

17 Van de Kar LD. Neuroendocrine pharmacology of serotoninergic (5-HT) neurons. Annual Review of Pharmacology and Toxicology $199131289-320$

18 Haack D, Möhring J, Möhring C, Petri M \& Hackenthal E. Comparative study on development of corticosterone and DOCA hypertension in rats. American Journal of Physiology 1977233 F403-F411.

19 Bohus B \& Koolhaas JM. Stress and the cardiovascular system: central and peripheral physiological mechanisms. In Stress From Synapse to Syndrome, pp 76-119. Eds SC Stanford \& P Salmon. London: Academic Press, 1993.

20 Phillips LS \& Young HS. Nutrition and somatomedin I. Effect of fasting and refeed on serum somatomedin activity and cartilage growth activity in rats. Endocrinology 197699 304-314.

21 Tannenbaum GS, Epelbaum J, Colle E, Brazeau P \& Martin JB. Antiserum to somatostatin reverses starvation-induced inhibition of growth hormone but not insulin secretion. Endocrinology 1978 102 1909-1914.

22 Brook CGD, Hindmarsh PC \& Stanhope R. Growth and growth hormone secretion. Journal of Endocrinology $1988119179-184$.

23 Straus DS. Nutritional regulation of hormones and growth factors that control mammalian growth. FASEB Journal 19948 6-12.

24 Rivier C \& Vale W. Corticotropin-releasing factor (CRF) acts centrally to inhibit growth hormone secretion in the rat Endocrinology $19841142406-2411$.

25 Rivier C \& Vale W. Involvement of corticotropin-releasing factor and somatostatin in stress-induced inhibition of growth hormone secretion in the rat. Endocrinology $19851172478-2482$.

26 Giustina A \& Wehrenberg WB. The role of glucocorticoids in the regulation of growth hormone secretion. Trends in Endocrinology and Metabolism 19923 306-311.

27 Thakore JH \& Dinan TG. Growth hormone secretion: the role of glucocorticoids. Life Sciences 199455 1083-1099.

28 Armario A \& Castellanos JM. A simple procedure for direct corticosterone radioimmunoassay in the rat. Revista Española Fisiologia $198440437-442$.

29 Daughaday WH, Mariz IK \& Blethen SL. Inhibition of access of bound somatomedin to membrane receptor and immunobinding sites: a comparison of radioreceptor and radioimmunoassay of somatomedin in native and acid-ethanol-extracted serum. Journal of Clinical Endocrinology and Metabolism $1980 \quad 51$ 781-788.

30 DiMarchi R, Long H, Epp J, Schoner B \& Belagaje R. Synthesis of insulin-like growth factor I through recombinant DNA techniques and selective chemical cleavaje at tryptophan. In Synthetic Peptides: Approaches to Biological Problems, vol 86, pp 283-294. Eds JP Tam, ET Kaiser. UCLA Symposia on Molecular and Cellular Biology New Series. New York: Ala R Liss Inc., 1989.

31 DiMarchi R, Long H, Epp J, Schoner B \& Belagaje R. Biosynthesis and characterization of insulin-like growth factor I (IGF-I). In Peptides, Chemistry, Structure and Biology. Proceedings of the
Eleventh American Peptide Symposium, pp 99-100. Eds JE Rivier \& GR Marshall. Leiden: ESCOM, 1990.

32 Paxinos G \& Watson C. The Rat Brain in Stereotaxic Coordinates. 2nd ed. London: Academic Press, 1986.

33 Miesfeld R, Rusconi S, Godowski PJ, Maler BA, Okret S, Wikstrom A-C et al. Genetic complementation of a glucocorticoid receptor deficiency by expression of cloned receptor cDNA. Cell $198646389-399$.

34 Gómez F, Lahmame A, De Kloet ER \& Armario A. Hypothalamicpituitary-adrenal response to chronic stress in five inbred rat strains: differential responses are mainly located at the adrenocortical level. Neuroendocrinology 199663 327-337.

35 Siiteri PK, Murai JT, Hammond GL, Nisker JA, Raymoure WJ \& Kuhn RW. The serum transport of steroid hormones. Recent Progress in Hormone Research 198238 457-510.

36 Gruen $\mathrm{PH}$. Endocrine changes in psychiatric diseases. Medical Clinics of North America 197862 285-296.

37 Davis M. The role of the amygdala in fear and anxiety. Annual Review of Neuroscience 199215 353-375.

38 Swiergiel AH, Takahashi LK \& Kalin HH. Attenuation of stressinduced behavior by antagonism of corticotropin-releasing factor receptors in the central amygdala in the rat. Brain Research 1993 $623229-234$.

39 Wiersma A, Bohus B \& Koolhaas JM. Corticotropin-releasing hormone microinfusion in the central amygdala diminishes a cardiac parasympathetic outflow under stress-free conditions. Brain Research 1993625 219-227.

40 Kalin NH, Takahashi LK \& Chen F-L. Restraint stress increases corticotropin-releasing hormone mRNA content in the amygdala and paraventricular nucleus. Brain Research 1994656 182-186.

41 Merlo Pich E, Lorang M, Yeganeh M, Rodriguez de Fonseca F, Raber J, Koob GF et al. Increase of extracellular corticotropin-releasing factor-like immunoreactivity levels in the amygdala of awake rats during restraint stress and ethanol withdrawal as measured by microdialysis. Journal of Neuroscience 199515 5439-5447.

42 Holly JMP \& Wass JAH. Insulin-like growth factors; autocrine, paracrine or endocrine? New perspectives of the somatomedin hypothesis in the light of recent developments. Journal of Endocrinology $1989122611-618$.

43 Berelowitz M, Firestone SL \& Frohman LA. Effects of growth hormone excess and deficiency on hypothalamic somatostatin distribution. Endocrinology 1981109 714-719.

44 Berelowitz M. Szabo M, Frohman LA, Firestone SL \& Chu L. Somatomedin-C mediates growth hormone negative feedback by effects on both the hypothalamus and the pituitary. Science 1981 212 1279-1281.

45 Tannenbaum GS, Guyda HJ \& Posner BI. Insulin-like growth factors: a role in growth hormone negative feedback and body weight regulation via brain. Science 1983229 77-79.

46 Rogers KV, Vician L, Steiner RA \& Clifton DK. The effect of hypophysectomy and growth hormone administration on preprosomatostatin messenger ribonucleic acid in the periventricular nucleus of the rat hypothalamus. Endocrinology 1988122 586-591.

47 Bertherat J, Timsit J, Bluet-Pajot MT, Mercadier JJ, Gourdji D, Kordon $\mathrm{C}$ et al. Chronic growth hormone $(\mathrm{GH})$ hypersecretion induces reciprocal and reversible changes in mRNA levels from hypothalamic GH-releasing hormone and somatostatin neurons in the rat. Journal of Clinical Investigation 199391 1783-1791.

48 Pellegrini E, Bluet-Pajot MT, Mounier F, Bennett P, Kordon C \& Epelbaum J. Central administration of a growth hormone $(\mathrm{GH})$ receptor mRNA antisense increases GH pulsatility and decreases hypothalamic somatostatin expression in rats. Journal of $\mathrm{Neu}$ roscience $1996168140-8148$.

49 Graeff FG. Role of 5-HT in defensive behavior and anxiety. Reviews in the Neurosciences $19934181-211$.

Received 18 November 1998

Accepted 24 May 1999 